\title{
Can non typical traditional forms of sacral space serve as a guide in the development of new forms of religious architecture in Serbian Orthodox Church?
}

¿Pueden las formas tradicionales atípicas de espacio sacro servir de guía en el desarrollo de nuevas formas de arquitectura religiosa de la Iglesia Ortodoxa Serbia?

Bozidar Manic, Igor Maric, Ana Nikovic · Institute of Architecture and Urban \& Spatial Planning of Serbia

https://doi.org/10.17979/aarc.2013.3.0.5083

\section{RESUMEN}

Este artículo presenta las posibilidades de desarrollo de nuevas formas de arquitectura religiosa en la Iglesia Ortodoxa Serbia, sobre la base de ciertas tradiciones. La situación actual en este ámbito se analiza con especial énfasis en los edificios y espacios religiosos atípicos. Los autores muestran que la dominación del tradicionalismo en la expresión arquitectónica no está basada en restricciones canónicas, sino el resultado del esfuerzo de establecer la continuidad interrumpida mediante la imitacion de formas de épocas anteriores. La libertad de creación arquitectónica en este campo se justifica observando con la variedad de las formas existentes a través de la historia, entre las cuales los zapis son particularmente interesantes.

\section{ABSTRACT}

This paper presents the possibilities of the development of new forms of religious architecture in Serbian Orthodox Church, on the basis of certain traditions. Current situation in this field is analyzed with special emphasis on non-typical religious buildings and spaces. The authors show that the domination of traditionalism in architectural expression is not based on the canonical restrictions, but rather the result of striving to establish the interrupted continuity by replicating forms from previous époques. Freedom of architectural creation in this field is strongly supported with the variety of forms existing through history of which zapis is particularly interesting.

\section{PALABRAS CLAVE}

Arquitectura; tradición; contemporáneo; Iglesia Ortodoxa Serbia; zapis (inscripción).

\section{KEYWORDS}

Architecture; Tradition; Contemporary; Serbian Orthodox Church; Zapis (inscription). 

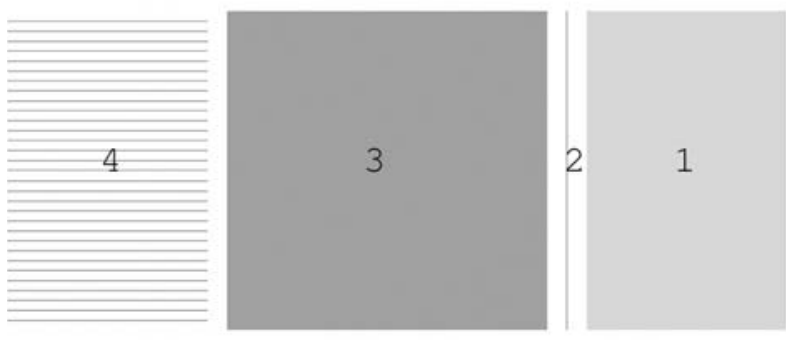

Fig. 01. Basic functional diagram of a church.

1.

Christian religious architecture after its initial appearance over the first four centuries A.D. developed in continuity only within the framework of the Western Christianity, while in the eastern one the development line was interrupted due to historic circumstances ${ }^{1}$. The model of inscribed cross that prevailed in Byzantine Empire and countries under its cultural influence from the time of Iconoclasm became the paradigm of an Orthodox temple. This model is dominant in the Serbian religious architecture as well, although it had its separate development path within the wider Byzantine cultural context, with elements of western influences and its own specific architectural solutions.

The crisis of ideas in the area of religious architecture and the discrepancy between the modern architectural concepts and the church building is characteristic for this and previous century, and is particularly evident in the Orthodox Christianity, due to attempts to reestablish the interrupted continuity, which resulted in the domination of historicism in architecture. This approach is often justified by canonical reasons.

The main problem of the modern Serbian sacral architecture is that it is too often copying the historical models ${ }^{2}$, neglecting the differences between the context in which they were created and the current moment,
1 altar (sanctuary)

2 altar barrier (iconostasis, templon)

3 space for faithful

4 space for catechumens and penitents (inside or outside the church) thus resulting in lack of authenticity in both forms and decorations.

Numerous specific historic examples can lead us to one potential way out of this situation. It is also necessary to point to the exact spatial and functional requirements that need to be met in order to be able to perform Christian ceremonies and also to segregate canonical and mandatory elements from these common and generally accepted that can be altered and further developed.

Functional organization of Orthodox Church is defined by character and rituals of worship as well as the structure of the church community ${ }^{3}$. Changes in liturgy that occurred during the two-millennium development of Christianity have always reflected on the architectural solutions of the temples. This functional reflection was never one-way, and so throughout history various models were used in parallel, even within one cultural region. Any future potential liturgy reform, judging by the issues that are relevant today, will not significantly influence the spatial organization of the temple, but could possibly leave its mark on some elements of interior decoration ${ }^{4}$.

In order for liturgy to be done, gathering of religious followers is necessary, and the service is done by the ordained priest. Also, service cannot be done without antimins ${ }^{5}$. Serving the liturgy outside of temples was a relatively common practice in early Christianity, 


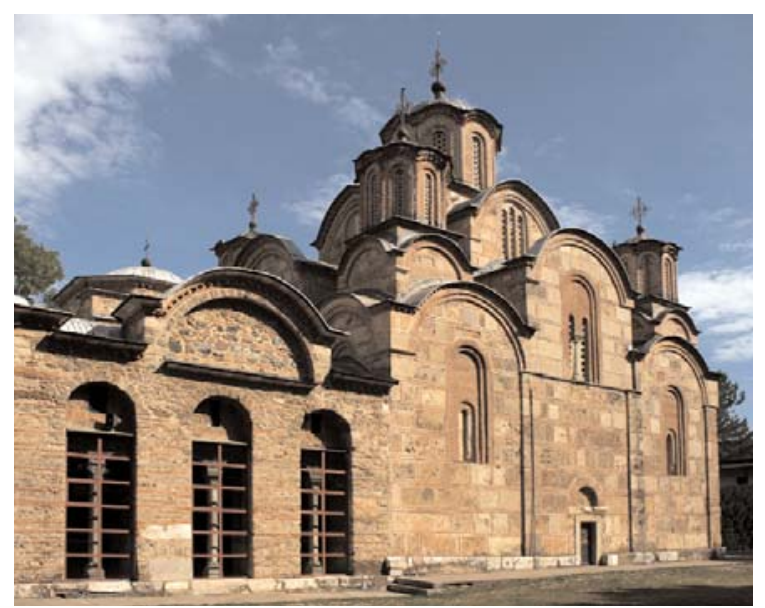

Fig. 02. Graèanica monastic church, 1321.

and is still allowed today, in exceptional cases, when the service can be done only on antimins, in chapels and other facilities, as well as open areas.

By its canons the Orthodox Church defines, indirectly, only the most general issues of temples' organization. Church canons define the following: a temple can be erected only with the approval of the bishop; the temple must be dedicated to the sacral relics of a martyr; it should have an altar area segregated from the rest of the building and with limited access; it should have an area for those unbaptized and pennants; it should be facing east; it should have a cross insignia and icons ${ }^{7}$. The details of functional organization and formal characteristics are not mentioned, and therefore it is clear that justification for historicist architecture is not founded in the canons.

\section{2.}

There is a big number of different forms that were used in early Christian, Byzantine and Serbian medieval church building, even after the final definition of the Byzantine liturgy. The Serbian church architecture shows the greatest diversity in its early beginnings. During the first phase of its development, basilicas, single-nave dome, triple apsidal and cruciform churches were built simultaneously. With the final establishment of the state and the development of three main archi- tecture schools, specific shapes, characteristic for each of them, start to be distinguished. However, the common denominator of the churches from mid and late Byzantine era, including those in Serbia, is the same spatial organization as well as the dome shared by majority of buildings. From 18th century western influences begin to reappear and that is when baroque and classic single-nave temples are built in the territories under Habsburg Monarchy rule. After the liberation of Serbia from Ottoman rule, attempts of renewal of medieval tradition are made, with predominant cruciform type with dome, which continue to date.

The religious buildings erected in the recent times by the Serbian Orthodox Church predominantly include the main liturgical objects - parish churches. This is because from the end of World War Two to the last decade of the 20th century, the building of new temples was obstructed ${ }^{8}$ and so with the liberalization of religious rights the need appeared to increase the capacities as well as to make a symbolic discontinuity from socialism and atheism. The parish churches, together with the monastery churches, can be considered the typical form of sacral buildings both today and throughout history.

Apart from these two types of sacral objects, others we could consider atypical, are very rare. The others include chapels in cemeteries and other memorial areas, chapels in hospitals and military barracks, open areas 


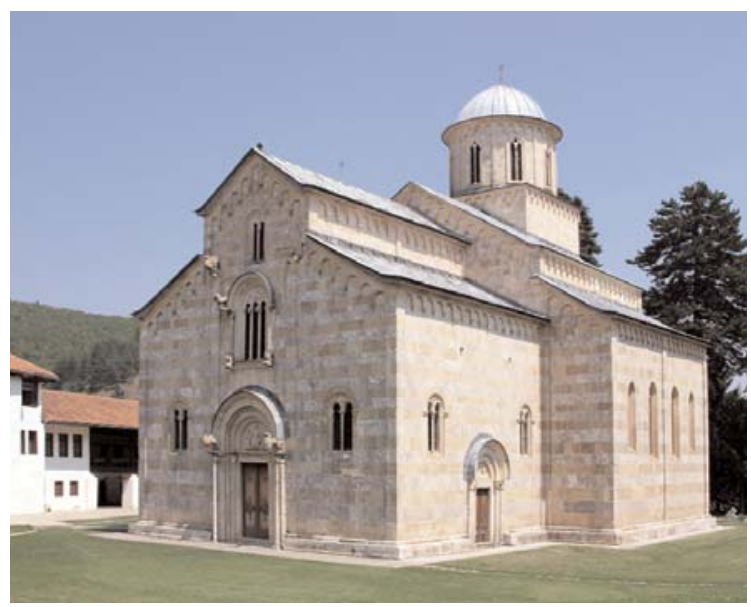

Fig. 03. Visoki Decani monastic church, 1327/35.

crosses and temporary prayer facilities. All these forms of religious objects are rare nowadays, for various reasons. Chapels in cemeteries are generally intended for funerals of deceased of all religions as well as atheists, and are only occasionally used for Christian ceremonies. Within the various memorial areas, there are usually existing tombs, monuments and museums and therefore there is rarely enough space to erect new temples. Chapels in hospitals have only started being used as of recently, still in small numbers they are for now mostly confined to regular hospital premises minimally refurbished for the needs of religious services. Priests have only recently been reinstituted in the military in Serbia and there is neither modern practice nor modern experience there. Erecting of crosses in public areas is very rare, while mass prayers and services in the open do not include any considerable architectural intervention in the open area'.

Praying areas created in converted apartments or houses, like the temples of Orthodox Archbishopric of Ohrid, which has been the subject of government pressure and occasional persecution in the Former Yugoslav Republic of Macedonia, are rather specific.

There are several highly significant traditional atypical forms of sacral areas for Orthodox Serbs, and the most significant ones for them are the praying or religious service open areas - zapis (inscription).

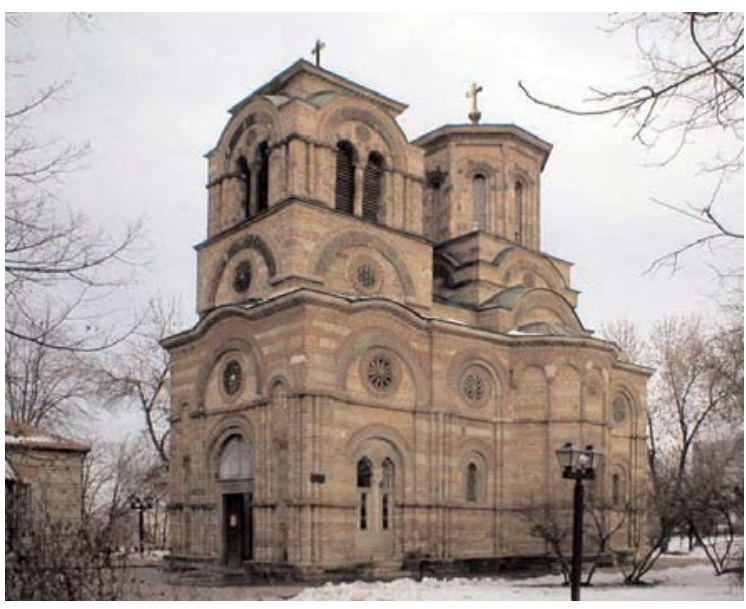

Fig. 04. Holy First Martyr Stephen, Lazarica, Krusevac, 1380.

Zapis is a tree (most commonly oak, but can also be wild pear etc.) with an inscribed cross ${ }^{10}$. This tree is a taboo and considered sacred, as well as the area around it. It is usually fenced off and a large cross may be erected next to $\mathrm{it}^{11}$. Zapis can, less frequently, be a regular wooden cross $^{12}$, and quite frequently instead of trees, which are dominant in numbers, some settlements used to erect crosses $^{13}$. Zapis has a very important role for both religious and social life of settlements, and becomes particularly important during the village saint festivity — slava ${ }^{14}$ — village patron saint's day.

On the day of the village festivity members of all village families take part in the procession through the entire village, from one sacred place to another. The procession starts at the church or the main zapis if there is no church in the village, and passes by all crosses and zapis in the village, only to return to the starting point. This custom can be interpreted in several ways; on one hand it can be seen as the remainder of the pagan fertility and rain invoking rituals or rituals for protection from natural disasters, while on the other it can be interpreted as the ritual of sacralisation of people and area of the village and a way of expanding the church domain with the aim of prayer mission in the world ${ }^{15}$. Common for all processions is that the prayer is not executed only through words but also movement ${ }^{16}$, thus embodying the dynamic nature of Christian liturgy discussed by Schmemann ${ }^{17}$. 


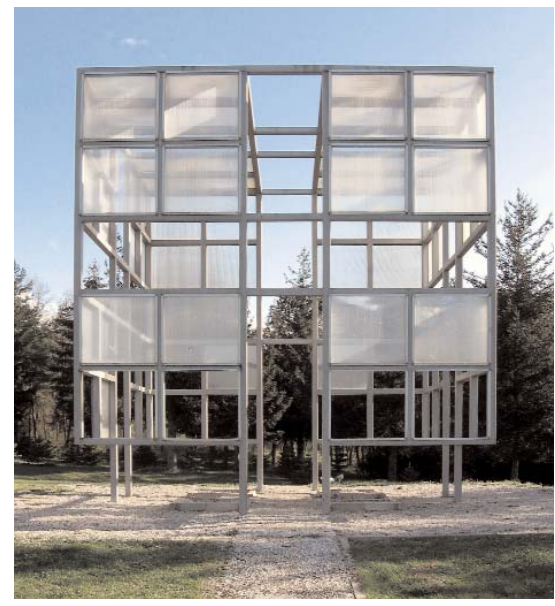

Fig. 05. Sasa Budevac, Chapel in Bubanj Memorial Park, Nis, 2003.

Apart from its role in the procession during the village saint festivity, zapis is a place where weddings, baptizing and other religious ceremonies and prayers can be done, even liturgies, particularly in the villages that don't have churches ${ }^{18}$. That way zapis becomes the village church.

The procession tradition (cross-bearers) that used to be very strong in Serbia, was almost completely extinguished after II World War, when religious processions outside the church yard were forbidden ${ }^{19}$. This lead to village saint festivities becoming increasingly smaller and confined to church yards, without village processions. However, old trees —zapis - remained taboos, which resulted in frequent cases of interruption or complete abandonment of constructions works due to avoiding to cut or dislocate zapis ${ }^{20}$.

\section{3.}

Religious buildings have the spatial organization that is conditioned by worshipping needs, while their form is defined more by cultural structures and perception of the symbolic meaning than church rules, which is primarily architectural problem, same as their function is primarily liturgical issue. Therefore, conserving church canons when copying traditional forms is unacceptable both from god worshipping and architectural point of view. Historicism as an approach to solving architectur-

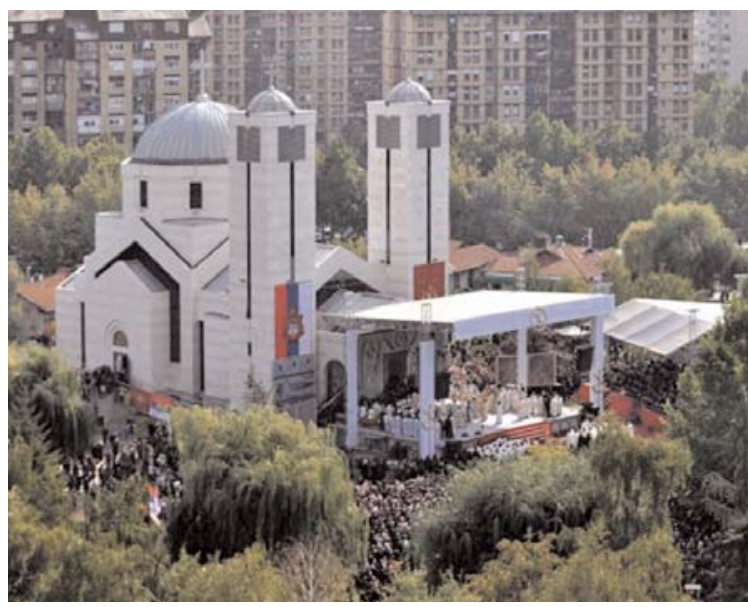

Fig. 06. St. Constantine and Helen, Nis, during the celebration of 1700 years of Edict of Milan, 2013.

al problems can be accepted as an expression of individual author's poetics in the time of pluralism of artistic and theoretical concepts, such as today, but the question remains which tradition is being renewed and what is the reference era. As both architecture and liturgy went through changes, the invoking of randomly chosen models is turning out to be not plausible and in its essence pseudo-traditional.

Traditionalism emerges due to the appearance of discontinuity in the architectural tradition, as an attempt to preserve religious and national identity in a hostile environment where the historic forms of Serbian medieval churches become the symbol of continuity, individuality and unity of a community. In the period after WWII, when the church is fighting for survival in an ideologically hostile environment, insisting on traditional forms on one hand represents the search for shelter in that what is familiar, while on the other hand it is a consequence of the lack of interest of the architect profession for church building. This type of development and lack of acceptance of novelties are stimulated by the character of modern architecture which, striving for abolition of the fiction ${ }^{21}$ has led to abolishment of symbolic and meaningful content, which are of extraordinary significance for religious awareness and cognition. Resorting to historic forms after the fall of communism becomes a significant element of reconstruc- 


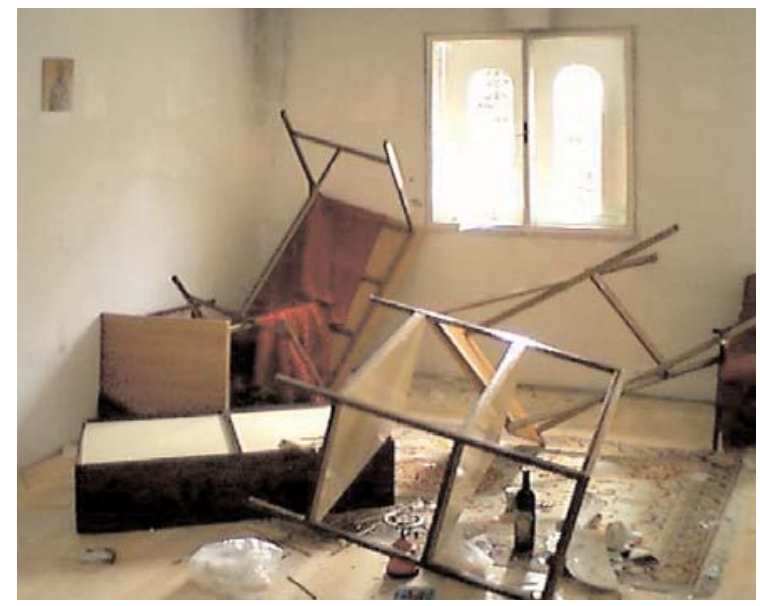

Fig. 07. Chapel of St. Nectarios of Aegina (adapted from prefabricated house), Skopje, after the demolition, 2005.

tion of religious and national identity ${ }^{22}$. Forms of church architecture become the symbol of respect for tradition, while their primary theological and cosmological symbolism becomes less important.

Invoking the tradition is nowadays being turned into formalism in the Serbian church architecture, as the architectural elements are not used for their primary meaning but for their historic significance, which points to the lack of knowledge and lack of understanding of the fundamentals of the architectural tradition which is thus becoming merely a justification for historicist author poetics. This seemingly fits the courses of the belated Serbian postmodernism, but fundamentally, due to loss of distinction between the new and historic, it represents the negation of postmodern pluralism and leads to the loss of authenticity ${ }^{23}$. The lively tradition that existed in the mid-ages was only a loose framework that directed the building activity, which is verified not only by the differences between three most important Serbian architecture schools, but also within each of them individually. The achievements of the church architecture and art in the middle ages represented the highest achievements of their time, which is not the case today. The resistance to modern trends which can be understandable only when it represents the reserve towards becoming trapped by ephemeral architectural trends, is thus becoming anachronism, which cannot produce satisfying results.
The freedom of architectural creativity is strongly underpinned by the richness of forms created throughout history, which are still, regardless of style differences, equally used for religious services. This can be supported by an example of zapis, as well as some other types of open air churches, and various other specific cases like underground and cave churches, transforming housing and other accommodation into worshipping spaces and use of temples of other religious communities, which is a frequent case in diaspora. It is particularly the last example that demonstrates that to the church as an Eucharistic community from the point of view of liturgical theology, it is much more important to bring together its followers than the architectural structure in which all this is taking place. Therefore it can be concluded that the form of temple is influenced by the dominant cultural structures that have the effect on the creation of symbolic systems and perception of tradition than the church rules.

Non-typical traditional forms of sacral space, although most frequently not a model to be copied, point to the freedom of design and construction of religious objects. Zapis cannot be a direct model for further development of church building, because its purpose is specific. The existence of this type of sacral space is a significant example that demonstrates that ceremonies can be performed in various spatial environments and 


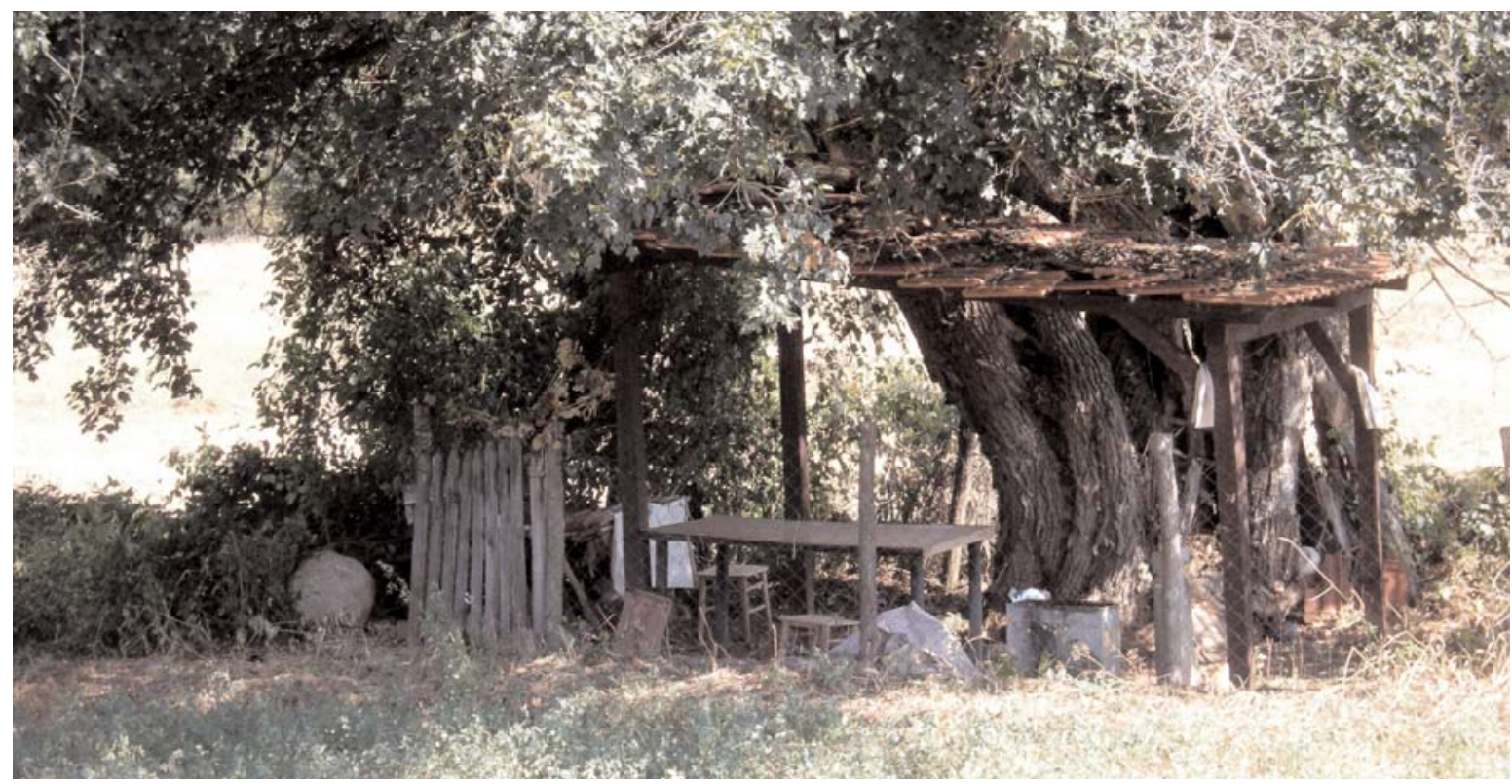

Fig. 08-09. Zapis, Vrtovac (Serbia).

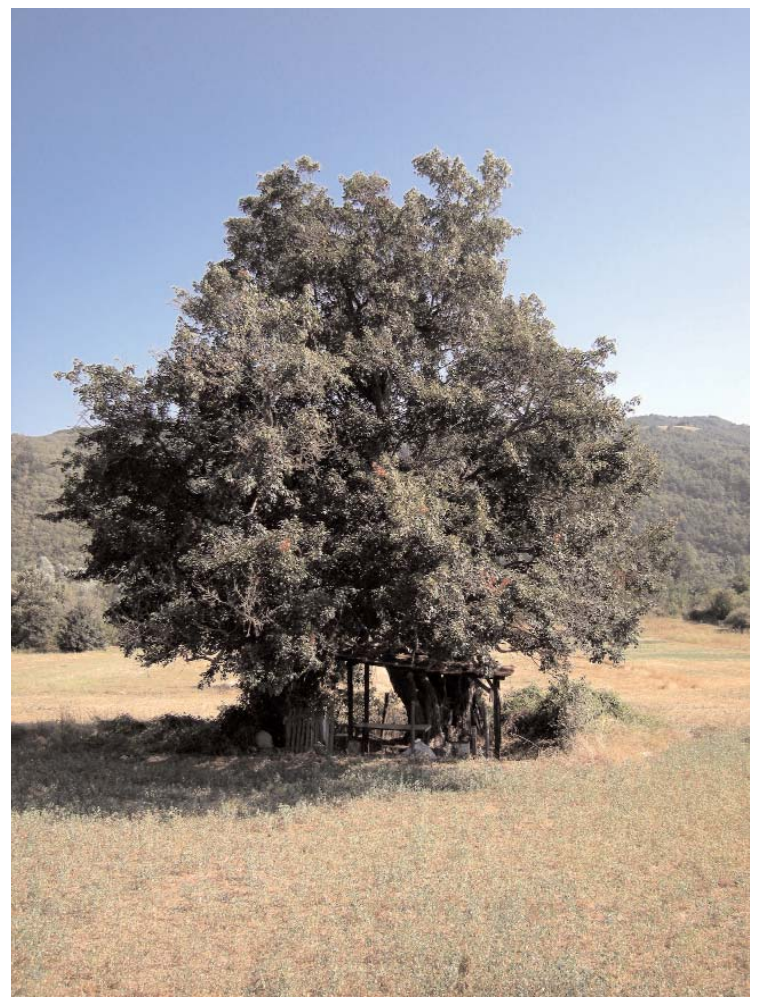

that for God's service the important thing should be the liturgical, Eucharistic community, not a specific space and building form.

\section{CREDITS OF IMAGES}

Fig. 01. Author's archive.

Fig. 02. Quinn Dombrowski,

http://commons.wikimedia.org/wiki/File:Graèanica.jpg.

Fig. 03. Julian Nitzsche,

http://sr.wikipedia.org/wiki/Äàô òåèà:Visoki_Decani.jpg.

Fig. 04. http://sh.wikipedia.org/wiki/Datoteka:Krusevac lazarica.jpg.

Fig. 05. http://en.wikipedia.org/wiki/File:Bubanj-

Budjevac.jpg.

Fig. 06. Nikola Dimitrijevic (Tanjug),

http://www.tanjug.rs/fotodet.aspx?galID=106157.

Fig. 07. http://svnektarij.wordpress.com/rusenjeto-na-stariotparaklis/.

Fig. 08-09. Igor Maric

\section{NOTES}

(1) In Serbia during the Ottoman Empire, between XV and XIX century, and during the socialist rule, from World War II to the last decade of the 20th century.

(2) Most frequently monuments of Morava architectural school from second half of 13th century that are considered to be authentic Serbian, or Gracanica which is from the golden era of the Serbian medieval state (first half of 13th century). 
(3) The treatment of those unbaptized and pennants are interesting. Overall social system is reflected through possible segregation of women or persons of power.

(4) In the Orthodox church, the liturgy renewal movement doesn't exist in the same form as in Western Christianity, although there are some ideas going in that direction (see Vladimir Vukašinovic, Liturgijska obnova u XX veku: istorijat i bogoslovske ideje liturgijskog pokreta u Rimokatolièkoj crkvi i njihov uzajamni odnos s liturgijskim ž ivotom Pravoslavne crkve [translation] (Belgrade: Áîâi ñêîânêè ôàêóëòåò Ñðïñêå İðàâî ñëàâíå Öðêâå, 2001), 113). Some of the questions that arise in regards to the structure and form of liturgy can affect the development of the church architecture. Namely, the topics increasingly discussed lately within the Orthodox Church include the following: size of iconostasis; opening of altar doors; role of pulpit in non-Eucharistic segments of the liturgy; position of prothesis (proskomedia); reform of the church chanting and the question of abolishing the quires (see Vukašinovic, Liturgijska obnova, 117-156). All these issues pertain to the internal organization and the functioning of temples, while the issue of the form is not being discussed.

(5) Justin (Popovic), Dogmatika pravoslavne crkve III [prevod] (Belgrade: Zaduž bina Sveti Jovan Zlatousti Ave Justina Celijskog, 2004).

(6) As evidenced by Eusebius: «And every place of affliction was to us a place of festival: field, desert, ship, inn, prison» (see Eusebius Pamphilius, "Church History», in Church History, Life of Constantine, Oration in Praise of Constantine, ed. Philip Schaff, vol. 7 of A Selected Library of the Nicene and PostNicene Fathers of the Christian Church, eds. Philip Schaff and Henry Wace (Grand Rapids, Michigan: WM. B. Eerdmans Publishing Company), accessed September 30, 2013, http://www.ccel.org/ccel/schaff/npnf201.iii.xii.xxiii.html, VII 22:4).

(7) See Bož idar Manic, «Pristup prouèavanju novije sakralne arhitekture u Srbiji - analiza mogucnosti razvoja modela pravoslanog hrama [An Approach to Studying New Sacral Architecture in Serbia - Analysis of the Possibilities for Developing the New Models of Orthodox Temple]», (MSc thesis, University of Belgrade, 2009), 120.

(8) Aleksandar Kadijevic \& Miroslav Pantovic, «The Concepts and Identity of the New Serbian Orthodox Ecclesiastical Architecture (1990-2009)» (paper presented at the II Congreso Internacional de Arquitectura Religiosa Contemporenea, Ourense, Spain, November 12-14, 2009). Cf. Kadijevic \& Pantovic, «Los conceptos y la identidad en la nueva arquitectura ortodoxa serbia (1990-2009)», Actas del Congreso Internacional de Arquitectura Religiosa Contemporenea 2-II (2011): 30-39, accessed September 30, 2013, http://www.arquitecturareligiosa.es/index.php/AR/article/view/83/41.
(9) During the recent celebration of 1700 years of Milan Edict in Nis, which was the gathering of the highest Orthodox Church clerics in recent times, only a small roof top was erected outside the church in the form of roofed exo-nartex.

(10) The cross is carved in on the western side (Nadež da Pešic Maksimovic, Spomenièke vrednosti seoskih centara u Srbiji [Les valeures des centres ruraux de Serbie] (Belgrade: Republièki zavod za zaštitu spomenika kulture, 1984), 23).

(11) Svetlana Tolstoj and Ljubinko Radenkovic, eds., Slovenska mitologija, enciklopedijski reènik [Slavic mythology, encyclopedic dictionary] (Belgrade: Zepter Book World, 2001), 189.

(12) Ivica Todorovic, Ritual uma. Znaèenje i struktura litijskog ophoda [The Ritual of the Mind. Meaning and Structure of the Procession Rite] (Belgrade: Etnografski institut SANU, 2005), 35-36.

(13) In Donemtian's Life of Saint Sava, who is the most prominent Serbian saint, it was documented that Saint Sava used to erect crosses in places where churches could not be built.

(14) Slava is a specific Serbian Christian tradition and represents the festivity celebrating the saint protector which is unique to each individual family and village/settlement in Serbia.

(15) Ivica Todorovic, «Hrišcanska i prethrišcanska dimenzija rituala litijskog ophoda [Christian and Pre-Christian Dimension of Ritual Procession]», Bulletin of the Ethnographical Institute SASA (47): 273.

(16) Todorovic, Ritual uma, 192.

(17) Šmeman points out that the service is based on the principle of procession, which symbolizes human movement towards God and God toward men, and the height of that movement is Eucharist (see Aleksandar Šmeman [Alexander Schmemann], Liturgija $i$ ž ivot [Liturgy and Life] (Cetinje: Mitropolija Crnogorsko-primorska i Skenderijska, 1992), 117-118).

(18) Tolstoj and Radenkovic, Slovenska mitologija, 189.

(19) Todorovic, Ritual uma, 190.

(20) Recently, after pressure exerted by the public, a highway route had to be modified in order to avoid cutting a tree with zapis in Savinac village. Also, after several attempts zapis in village Vreoci had to be moved because it was blocking the expansion of the largest coal mine in Serbia.

(21) See Hajnrih Kloc [Heinrich Klotz], Umetnost u XX veku: moderna - postmoderna - druga moderna [Kunst im 20. Jahrhundert: Moderne — Postmoderne — zweite Moderne] (Novi Sad: Svetovi, 1995).

(22) Continuation of construction of Saint Sava temple in Belgrade which is significant for reviving of church architecture and for strengthening the national awareness during the 80 -es and 90-ies of the 20th century.

(23) See Kloc, Umetnost, 149-153 